\title{
Disentangling The Effects Of The Employee Benefits On Employee Productivity
}

\author{
Dong Ug Kang, Korea National University of Welfare, South Korea \\ Gun Jea Yu, Hongik University, South Korea \\ Sang-Jik Lee, Hoseo University, South Korea
}

\begin{abstract}
This study aimed to investigate the effects of employee benefits on employee productivity. There are conflicting views, positive and negative, with regard to the effect of employee benefits on employee productivity. Overall, we found that employee benefits have a positive impact on employee productivity through the embodied effect (direct effect). Specifically, according to a workplace panel survey in Korea conducted between 2005 and 2009, an in crease of one unit in employee benefits leads to an increase of employee productivity by about 7.9\%. In addition, we found that such effect is stronger in the manufacturing industry than in the non-manufacturing industry. Although there is no difference in the effect of benefits between large firms and small and medium-sized firms, the labor-embodied effect is stronger in large firms, and the capital-embodied effect is salient in small and medium-sized firms.
\end{abstract}

Keywords: Employee Benefits; Employee Productivity; Embodied And Disembodied Effect; Panel Data

\section{INTRODUCTION}

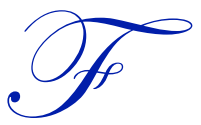

irms use various compens ation systems to boost employee productivity. These compensation systems aim at providing a reward in response to individual performance. However, benefits, one of the components of compensation systems, are provided in response to the affiliation of a firm, not to individual performance (Williams \& MacDermid, 1994). Hence, there are very few studies that have investigated the effect of benefits on individual or firm performance. Yet, it is important to understand the effect of benefits on individual or firm performance because the portion of benefits out of the total compensation is growing. A few of researchers argue that the benefits can also be offered to employees based on individual performance.

Benefits represent all forms of rewards, except monetary reward (Mikovich \& Newman, 1990). There have been conflicting arguments regarding the effect of benefits on employee performance. From the economic point of view, benefits negatively influence employees and firms. According to the agent theory and transaction cost theory, benefits increase moral hazard and free-rider problems among employees, thereby resulting in the increase of benefits costs of firms. On the other hand, other researchers argue that benefits increase employee motiv ation and in turn, the increased motivation positively influences both individual and firm performance.

This paper intends to investigate the effect of benefits on employee productivity in Korean firms. In addition, we investigate the conditions when the effect of benefits is salient to suggest proper implications for government policies.

\section{THEORETICAL BACKGROUND}

There have been conflicting arguments over the effect of benefits on firm performance. The negative relationship regarding such effect is supported by the agent theory and transaction cost theory. According to these two theories, employees (agent) pursue their interest rather than that of the firm (principle) due to the imbalance of information between the two actors as well as the imperfection of monitoring employees (Jensen and Meckling, 1976). In addition, there is a likelihood of employees' moral hazard and adverse selection (undesired results occur when the agent and principal have asymmetric information) due to asymmetric information. Therefore, agents execute their job even though the level of benefits increase and the likelihood of moral hazard and adverse selection do not change. In turn, employee productivity is not affected by benefits. 
On the other hand, the positive relationship between employee benefits and individual or firm performance has been also investigated. The expansion of employee benefits provides employees with motivation and in turn, the increased level of motivation prevents employee from quitting a job and help them develop. Finally, firm productivity or performance can increase as well. According to the labor turnover model, the opportunity costs of turnover are defined as the costs used for hiring employees and placing them through training and development (Hom, Caranikas -Walker, Prussia, and Griffeth, 1992). Such opportunity costs of turnover hinder firms' competitive advantage. Thus, competitive monetary compensation and benefits play an important role in preventing turnovers. Further, the expansion of benefits inhibits employee turnover and helps firms to keep capable employees.

Second, most components of benefits are positively related with individual satisfaction (Dulebohn, Molloy, Pichler, and Murray, 2008). Such positive relationship between the two increases the level of individual motivation and in turn, the increased level of individual motivation positively affects individual and firm performance. Such positive effect of benefits on individual motivation is explained by two theories. The two-factor theory suggests that employee benefits are categorized as a motivator to boost individual motivation. If a motivator is satisfied, an employee's individual motivation is improved. However, even though the motivator is not satis fied, the employee's motivation is not led to dissatisfaction. Therefore, the level of benefits increases individual motivation. The expectancy theory (Vroom, 1964) also provides support for the positive association between benefits and individual motivation. Individual motivation consists of three elements: expectation, instrumentality and valence. Benefits enhance the level of valence. This effect implies that benefits can improve individual motivation by increasing the level of valence if the other two elements are constant. In turn, the increased level of individual motivation positively influences individual productivity.

There are very few empirical researches on the effect of benefits on individual productivity. Most studies investigate the effect of a specific component of benefits rather than the overall level of benefits. For instance, employee stock ownership plan (ESOP) and flexible work schedule have been extensively studied. However, there are conflict empirical results on the effect of ESOP. Using a sample of Japanese firms, Jones and Kato (1993) found a positive relationship between the portions of employees who bought ESOP stocks and firm performance. On the other hand, Kruse (1992) suggested that there is no as sociation between ESOP and firm performance, using a sample of American firms. Researchers overall proposed that further studies are needed to investigate the effect of ESOP through utilizing an enhanced research design and better data. With regard to flexible work schedules, extensive studies have been performed due to the diverse forms of flexible work schedules. Pierce and Newstrom (1980) found that flexible work schedules engender employees to utilize their competency more effectively because employees can better understand their condition and do their best. Schein, Maurer, and Novak (1977) also discovered the positive effect of flexible work schedules on individual productivity using a sample of 246 employees in the manufacturing industry. However, these results were not extended to white workers (Kim \& Campagna, 1981).

Few studies investigate the direct relationship between the overall benefits and productivity. Firm productivity was measured in various ways. Some used indirect measures of firm performance, such as employee turnover, engagement or satisfaction (Dreher, Ash, \& Bretz, 1988; Micelli \& Lane, 1991). Others directly measured firm performance using employee motivation, added value per employee or sales per employee (Hong et al., 1995). Choi (1996) was the first to examine the relationship between benefits and productivity. He found that benefits positively affect firm productivity through increased motivation and the stability of the labor market. Kang (2002) also tested this relationship using 308 manufacturing firms. According to his results, benefit costs per emp loyee increased the added value per employee and sales per employee. Shin (2005) investigated the effect of intra-company labor welfare fund on employee productivity using the financial statements of unlisted and listed companies between 1992 and 2000. As a result, he noted a positive relationship between the two. In addition, he also found that such positive effect is stronger for small and medium-sized firms, meaning that the positive effect of benefits on employee productivity decreases as the size of the benefit target is larger. This impact implies that the socialization of benefits escalates the likelihood of moral hazard and employee free-riding and in turn, diminishes employee productivity. In sum, benefits have a positive impact on employee turnover (Kang and Kang, 1998), employee engagement and job satisfaction (Dulebohn, Molloy, Pichler, and Murray, 2008). 
In addition to the direct relationship between benefits and firm productivity, this paper investigates the factors which moderate this relationship. First, we consider two types of effects of benefits: embodied and disembodied effects. Theoretically, the effect of benefits can be categorized into a direct effect (i.e., embodied effect) and an indirect effect (i.e., disembodied effect). The embodied effect is defined as the effect that influences the productivity through elements of production. This effect is also categorized as the labor-embodied and capital-embodied effect. The laborembodied effect implies the increase of productivity through increased loyalty, increased labor intensity and decrease in absence. The capital-embodied effect means the increase of productivity through the maximization of a facility's utilization and the minimization of raw materials. On the other hand, the disembodied effect is the increase of productivity through favorable relations between the union and management and the increase of organizational efficiency (Shin, 2005). Second, we consider the characteristics of firms such as industry and size. The effect of benefits may differ by a firm's industry and size. In Korea, the size of benefits and working conditions are different according to a firm's industry and size, resulting in different effects of benefits on a firm's productivity.

This study contributes to the current literature in four ways. First, this study adopted the overall level of benefits, an important index for employee benefits. Shin (2005) concentrated on the intra-company welfare fund, which is a part of the employee benefits package. Considering the portion of the intra-company welfare fund to overall benefits (1.8\% $\sim 3.3 \%$ ), it is critical to examine the effects of the overall benefits on employee productivity. In addition, this study also investigated the different effects of benefits on employee productivity considering two types of effects (embodied versus disembodied effects) and firm type, such as large versus small and medium-sized firms and manufacturing versus non-manufacturing firms.

Second, we increased the generalizability by using a workplace panel survey (WPS), which extensively covers firms in Korea. The purpose of WPS is to acquire comparability among firms by sampling reprehensive firms by industry, size and region (Korea Labor Institute). For instance, Shin (2005) used a sample of 1,710 firms that have an intracompany welfare fund. This sample accounts for only 3\% of all firms whose financial statements are available in Korea. Therefore, there may be a generalizability issue in this sample.

\section{CURRENT STATE OF BENEFITS IN KOREA}

Benefits represent all costs used for employee welfare, except monetary rewards such as salary, bonus and overtime pay (Williams and MacDermid, 1994). Benefits are categorized into two: legal welfare expense and non-legal welfare expense. Legal welfare expense are those that are covered by law. It includes health insurance, pension, occupational health and safety insurance, and unemployment insurance. Non-legal welfare includes all costs, except legal welfare expense, such as intra-company welfare fund, dwelling expense and education cost.

Benefits per employee are on the rise. According to the Ministry of Employment and Labor in Korea, benefits per employee in 2005 were 385,900 won, but increased to 498,600 won (30\%) in 2012 (Table 1). However, benefits per employee decreased in $2008(6 \%)$ and in $2010(2 \%)$. These drops are explained by the fluctuation of legal and nonlegal welfare expense. With regard to legal welfare expense, there is a growing trend. On the other hand, non-legal welfare expense fluctuated during 2005 and 2012. For example, it dropped by $18 \%$ in 2008 and remained constant in 2009. In 2010, it dropped again by $9 \%$. In the subsequent year, it surged by $15 \%$ and dropped by a small margin. Therefore, it can be observed that the trend of benefits per employee seems to be influenced by non-legal welfare expense, not by legal welfare expense. The large drops of benefits per employee in 2008 and 2010 went along with those of non-legal welfare expense. Hence, non-legal welfare expense is more vulnerable to the external environment. In 2008, the subprime mortgage crisis influenced the world financial market. Consequently, this impact caused a decrease in non-legal welfare expense. 
Table 1. Employee benefits per employee (2005 2012)

\begin{tabular}{l|c|c|c}
\hline Year & Employee benefits & Legal employee benefits & Non-legal employee benefits \\
\hline 2005 & 385.9 & 208.2 & 177.7 \\
\hline 2006 & 436.6 & 228.6 & 208.0 \\
\hline 2007 & 468.0 & 243.6 & 224.4 \\
\hline 2008 & 440.3 & 255.5 & 184.8 \\
\hline 2009 & 444.2 & 259.1 & 185.1 \\
\hline 2010 & 436.0 & 266.7 & 169.3 \\
\hline 2011 & 475.6 & 280.1 & 195.5 \\
\hline 2012 & 498.6 & 296.8 & 201.8 \\
\hline
\end{tabular}

(Unit: 1,000 Won, 1 USD $=1,034.50 \mathrm{KRW})$

Source: Survey on the Labor Cost of Company (2005 2012), Ministry of Employment \& Labor (Korean Government)

With regard to the components of legal welfare expense, pension accounted for the largest portion, followed by health insurance, occupational health and safety insurance, and unemployment insurance (Table 2). Meal cost consisted of the largest part (39\%) in non-legal welfare expense, followed by otherexpenses, education cost and dwelling expense (Table 3).

Table 2. Legal employee benefits per employee

\begin{tabular}{l|c|c|c|c|c|c|c}
\hline Year & $\begin{array}{c}\text { Legal } \\
\text { benefits }\end{array}$ & $\begin{array}{c}\text { Health } \\
\text { insurance }\end{array}$ & $\begin{array}{c}\text { Health and safety } \\
\text { insurance }\end{array}$ & Pension & $\begin{array}{c}\text { Unemployment } \\
\text { insurance }\end{array}$ & $\begin{array}{c}\text { Disability } \\
\text { employment levy }\end{array}$ & others \\
\hline 2005 & 208.2 & 54.3 & 35.9 & 89.3 & 25.4 & 1.9 & 1.3 \\
\hline 2006 & 228.6 & 58.1 & 45.1 & 94.6 & 27.3 & 2.1 & 1.5 \\
\hline 2007 & 243.6 & 62.7 & 48.4 & 98.8 & 29.2 & 2.3 & 2.1 \\
\hline 2008 & 255.5 & 77.4 & 45.0 & 98.4 & 31.8 & 2.1 & 0.7 \\
\hline 2009 & 259.1 & 79.7 & 45.0 & 99.2 & 32.7 & 2.2 & 0.3 \\
\hline 2010 & 266.7 & 82.6 & 46.5 & 101.3 & 33.4 & 2.1 & 0.8 \\
\hline 2011 & 280.1 & 95.9 & 43.9 & 102.6 & 34.6 & 2.4 & 0.8 \\
\hline 2012 & 296.8 & 104.8 & 44.3 & 106.4 & 38.0 & 2.9 & 0.4 \\
\hline
\end{tabular}

(Unit: $1,000 \mathrm{Won}, 1 \mathrm{USD}=1,034.50 \mathrm{KRW})$

Source: Survey on the Labor Cost of Company (2005 2012), Ministry of Employment \& Labor (Korean Government)

Table 3. Non-legal employee benefits per employee

\begin{tabular}{c|c|c|c|c|c|c|c|c|c|c|c|c|c}
\hline Year & $\mathbf{1}$ & $\mathbf{2}$ & $\mathbf{3}$ & $\mathbf{4}$ & $\mathbf{5}$ & $\mathbf{6}$ & $\mathbf{7}$ & $\mathbf{8}$ & $\mathbf{9}$ & $\mathbf{1 0}$ & $\mathbf{1 1}$ & $\mathbf{1 2}$ & $\mathbf{1 3}$ \\
\hline 2005 & 177.7 & 10.2 & 7.8 & 74.1 & 9.6 & 6.6 & 16.3 & 8.4 & 0.5 & 4.0 & 6.0 & - & 34.9 \\
\hline 2006 & 208.0 & 11.9 & 8.4 & 77.5 & - & - & - & - & 0.8 & - & - & - & 109.4 \\
\hline 2007 & 224.4 & 13.4 & 9.2 & 82.2 & 15.3 & - & 25.8 & 15.6 & 0.9 & 13.9 & - & 4.5 & 43.6 \\
\hline 2008 & 184.8 & 13.7 & 9.8 & 72.6 & 9.9 & - & 23.3 & 11.6 & 0.8 & 11.4 & - & 1.4 & 30.3 \\
\hline 2009 & 185.1 & 14.8 & 10.7 & 73.1 & 10.1 & - & 24.3 & 8.0 & 1.1 & 10.9 & - & 0.9 & 31.2 \\
\hline 2010 & 169.3 & 11.4 & 9.4 & 68.4 & 9.5 & - & 20.6 & 9.0 & 1.3 & 10.7 & - & 2.1 & 26.9 \\
\hline 2011 & 195.5 & 15.9 & 12.4 & 77.5 & 10.0 & - & 23.7 & 9.6 & 1.3 & 12.5 & - & 0.5 & 32.2 \\
\hline 2012 & 201.8 & 14.6 & 12.0 & 81.7 & 10.7 & - & 24.4 & 10.7 & 1.7 & 13.4 & - & 0.7 & 32.0 \\
\hline
\end{tabular}

Source: Survey on the Labor Cost of Company (2005 2012), Ministry of Employment \& Labor (Korean Government)

1. Non-legal benefits

2. Residence expense

3. Health costs

4. Dining Costs

5. Insurance support fund

6. Expenses for congratulations and condolences

7. Education expense

8. Intra-Company Labor Welfare Fund

9. Child care fund 
10. Worker rest expense

11. Employee stock ownership plan

12. Employee's stock ownership fund

13. Others

\section{METHODS}

An increase in firm productivity is cause by the following two factors. First, the increased volume of factors of production, such as labor and capital, can increase a firm's output. Second, the changed method of using factors of production can also raise the level of a firm's output (Lee, 2012). Although the production function considers only labor and capital input, benefits can also positively influence a firm's output. For example, the increase in benefits has an impact on labor relations or firm culture (disembodied effect) or on the effective use of labor or capital (embodied effect) ${ }^{1}$. This relation is represented by the Cobb-Douglas production function (equation 1).

$Q=A(1+\delta X+\theta W) L^{\alpha} K^{\beta}$

Q refers to the volume of a firm's production, A is constant for effectiveness, $\mathrm{X}$ is a factor that influences a firm's production, except labor and capital, $\mathrm{W}$ is benefits, $\mathrm{L}$ is the number of employees, and $\mathrm{K}$ is the volume of a firm's capital. $\delta$ is an elasticity, except for labor and capital. $\theta$ is a disembodied elasticity of employee welfare. $\alpha$ is the labor elasticity of output and $\beta$ is the capital elasticity of output.

If the information of company (i) and time (t) were added to formula (1), the formula can be changed as follows.

$Q_{i, t}=A\left(1+\delta X_{i, t}+\theta W_{i, t}\right) L_{i, t}^{\alpha} K_{i, t}^{\beta}$

Formula (2) is expressed as equation (3), which reflects the disembodied and embodied productivity of employee welfare (Bloom, 1985; Kruse, 1992; Shin, 2005). Q (i,t) is the output of company (i) in the year of (t). W(i,t) is the employee welfare of company (i) in the year of $(\mathrm{t}) . \delta$ is the labor elasticity of output and $\alpha$ is the capital elasticity of output. $\theta$ is the labor-embodied effect of employee welfare and $\beta$ is the capital-embodied effect of employee welfare (Bloom, 1985; Kruse, 1992; Shin, 2005)²

$Q_{i, t}=A\left(1+\delta X_{i, t}+\theta W_{i, t}\right) L_{i, t}^{\alpha_{1}+\gamma_{1} W_{i, t}} K_{i, t}^{\alpha_{2}+\gamma_{2} W_{i, t}}$

The productivity effect of employee welfare can be estimated by equation (4). However, this equation was altered through the conversion of the logarithmic function and first order Taylor series expansion.

$Q_{i, t}=A\left(1+\delta X_{i, t}+\theta W_{i, t}\right) L_{i, t}^{\alpha_{1}+\gamma_{1} W_{i, t}} K_{i, t}^{\alpha_{2}+\gamma_{2} W_{i, t}}$

In equation (4), we can express total output $(\mathrm{Q}(\mathrm{i}, \mathrm{t}))$ as average output $(\mathrm{Q} / \mathrm{L}(\mathrm{i}, \mathrm{t}))$ and change the variable vector $(\mathrm{X})$ for each variable.

$\ln Q_{i, t}=\ln (A)+\delta X_{i, t}+\theta W_{i, t}+\alpha_{1} \ln \left(L_{i, t}\right)+\alpha_{2} \ln \left(K_{i, t}\right)+\gamma_{1} W_{1} \ln \left(L_{i, t}\right)+\gamma_{2} W_{2} \ln \left(K_{i, t}\right)$

Average output (Q/L) means labor productivity, and K/L implies capital intensity. RD/L and LC/L are vector variables. $\mathrm{RD} / \mathrm{L}$ means the research and development costs and $\mathrm{LC} / \mathrm{L}$ is the personnelexpense for one employee. D1 and D2 are dummy variables (training, labor union). Econ $n_{t}$ is the economic growth rate in the year t. $\pi_{t}$ is the industry-specific fixed effect and $\tau_{t}$ is the time effect. $\epsilon_{i, t}$ is the probability error term.

\footnotetext{
${ }^{1}$ Technological advance, labor union and organizational culture can also influence a firm's productivity. In this study, these factors are all controlled.

${ }^{2} \ln (1+\delta \mathrm{X} i, t+\theta \mathrm{W} i, t)$ is transformed from $\delta \mathrm{X} i, t+\theta \mathrm{W} i, t$ by the Taylor series expansion. According to the Taylor series expansion, $\ln (1+\delta+\theta)$ converges on $(\delta+\theta)$. Therefore, the effect of the disembodied effect is described as $(\delta \mathrm{X} i, t+\theta \mathrm{W} i, t)$.
}

Copyright by author(s); $\underline{\mathrm{CC}-\mathrm{BY}}$

The Clute Institute 
The result might be biased when the panel model is estimated through OLS or 2SLS regression because these two regressions tend to omit fixed firm-specific characteristics (i.e., information of company). For this reason, this study used the two-way fixed effect model, which controls the industry-specific fixed effect and time effect. The formula can be changed as below if both the industry-specific fixed effect and time effect are considered. We intensify the prediction of variables by controlling the variables that can influence productivity, such as labor union or the rate of economic growth (Kang, 2002; Kleiner and Lee, 1997).

$\ln \left(\left(\frac{Q}{L}\right)_{i, t}\right)=\ln (A)+\alpha_{2} \ln (K / L)+\alpha_{2} \ln (K / L)+\delta_{1} \ln \left((R D / L)_{i, t}\right)+\delta_{2} \ln ((L C /$

$\left.L)_{i, t}\right)+\delta_{3} D 1_{i, t}+\delta_{4} D 2_{i, t}+\theta W_{i, t}+\gamma_{1} W_{1} \ln \left(L_{i, t}\right)+\gamma_{2} W_{2} \ln \left(K_{i, t}\right)+\delta_{5} E_{c o n}+\pi_{i}+\tau_{t}+\epsilon_{i, t}$

\section{DATA}

Sample: The workplace panel survey (WPS), which contains comprehensive samples in various industries, has been conducted every two years. This survey was designed by the Ministry of Employment and the Labor and Korea Labor Institute in order to examine the status of employee development and labor supply and demand. It also aims at enhancing the government's labor policy and the effectiveness of employee development. Therefore, this survey is useful for understanding the trend of labor relations and employee development. Moreover, researchers can analyze the structure of human resource development, such as the compensation system, evaluation systemand reward system, and understand the characteristics of Korean labor relations.

WPS has been conducted for 1,626 for-profit organizations and 111 public organizations. As of 2009, 77.6 percent of organizations that had been the targets of this survey were maintained. The items of this survey includes the characteristics of organizations, status of employee, compensation and evaluation, human resources development, employee benefits, and industrial disaster. The target organization was selected by contacting potential target organizations. If an organization was chosen, the financial statements and status of employees were prepared. Subsequently, officers visited a target organization to conduct an interview. This interview was done using the computer assisted personal interviewing (CAPI), which was made by the Statistics department in the Netherlands. This study acquired 5,377 year-organization observations by using the data of three years (2005, 2007 and 2009). After examining the availability of sales, benefits, total capital, R\&D expenditure and the number of employees, the final year-organization observations were 2,915.

\section{Variables}

\section{Dependent Variables}

Value added per employee and sales per employee were used to capture firm productivity or labor productivity. In this study, we used sales per employee as a dependent variable (Table 4). Value added per employee has been widely used for labor productivity, which includes the labor cost, which contains the benefits ${ }^{3}$. Therefore, the use of value added as the dependent variable can cause a repetition of benefits, which then becomes the independent variable. However, the usage of sales per employee eliminates this problem ${ }^{4}$.

\section{Independent Variable}

The concept of benefits is classified into two concepts. The broad concept of benefits includes both legal ${ }^{5}$ and nonlegal welfare expense. On the other hand, the narrow concept of benefits includes only benefits, except legal welfare expense. We chose the first concept because we believe that it contains all aspects of benefits. Employee benefits were defined as the costs for employee benefits in income statement including legal benefits, healthy expense, supplies

\footnotetext{
${ }^{3}$ Added value can be defined in various ways. The Bank of Korea uses an additive way (added value $=$ operating profit + labor costs + financial cost + depreciation costs + tax and public imposition), whereas the Korea Development Bank uses a deductive way (added value $=$ out put - direct production costs). In this study, we adopted the additive way.

${ }_{5}^{4}$ Kruse (1992) and Kang (2002) used sales per employee as a measure of productivity.

${ }^{5}$ Legal welfare expense includes health and safety insurance, pension, unemployment insurance and employment for the disabled insurance fund. 
expense, food expense, and education cost in the survey (Williams \& MacDermid, 1994). Employee benefits were measured by the total costs of employee benefits divided by the total number of employees. We also incorporated the producer price index (PPI) due to the differences of prices among years when the data were collected $^{6}$.

\section{Control Variables}

We created several control variables at the organizational level in order to account for organizational characteristics; labor expense per employee, research and development expense per employee, capital intensity, total ass et, size (the number of employees), union and training. In addition to these organizational level control variables, we also created control variables over the industry level; industry, economic development rate and time (year).

Table 4. Description of variables

\begin{tabular}{l|l|l|l}
\hline \multicolumn{1}{c|}{ No } & \multicolumn{1}{|c|}{ Variable } & \multicolumn{1}{c}{ Description } & \multicolumn{1}{c}{ Measure } \\
\hline 1 & $\ln ($ Sale/L) & Sales per employee & Log transformation \\
\hline 2 & W & Benefits per employee & Log transformation \\
\hline 3 & TRAIN & Training program & Implementation=1, No implementation=0 \\
\hline 4 & UNION & Union & Exist $=1$, No exist=0 \\
\hline 5 & $\ln (\mathrm{L})$ & Total number of labor & Log transformation of the total number of labor \\
\hline 6 & $\ln (\mathrm{K})$ & Total asset & Log transformation of total asset \\
\hline 7 & $\ln (\mathrm{K} / \mathrm{L})$ & Capital intensity & Log transformation of capital intensity \\
\hline 8 & $\ln (\mathrm{LC} / \mathrm{L})$ & Wage per employee & Log transformation of wage per employee \\
\hline 9 & $\ln (\mathrm{RD} / \mathrm{L})$ & R\&D expense per employee & Log transformation of R\&D expense per employee \\
\hline 10 & ECON & A rate of economic growth & Percentage \\
\hline 11 & IND & $\begin{array}{l}\text { Industry dummy } \\
\text { (Manufacturing industry }=1)\end{array}$ & Industry classification code \\
\hline 12 & TIME & Year dummy & Year $(2005=1,2007=2,2009=3)$ \\
\hline
\end{tabular}

Table 5. Basic Statistics of Variables

\begin{tabular}{c|l|c|c|c|c|c|c|c|c|c}
\hline No & \multicolumn{1}{|c}{ Variable } & Mean & St.Dev & $\mathbf{1}$ & $\mathbf{2}$ & $\mathbf{3}$ & $\mathbf{4}$ & $\mathbf{5}$ & $\mathbf{6}$ & $\mathbf{7}$ \\
\hline 1 & $\ln ($ Sale/L) & 5.42 & 1.20 & 1 & & & & & \\
\hline 2 & $\mathrm{~W}$ & 1.71 & 2.06 & $.49^{* *}$ & 1 & & & & \\
\hline 3 & $\mathrm{~W}^{*} \ln (\mathrm{L})$ & 9.60 & 7.68 & $.31^{* *}$ & $.34^{* *}$ & 1 & & & \\
\hline 4 & $\mathrm{~W}^{*} \ln (\mathrm{K})$ & 18.87 & 6.44 & $.67^{* *}$ & $.61^{* *}$ & $.81^{* *}$ & 1 & & \\
\hline 5 & $\mathrm{UNION}$ & 0.46 & 0.50 & $.12^{* *}$ & $.05^{* *}$ & $.37^{* *}$ & $.31^{* *}$ & 1 & \\
\hline 6 & TRAIN & 0.90 & 0.30 & $-.08^{* *}$ & $-.09^{* *}$ & $-.17^{* *}$ & $-.16^{* *}$ & $-.06^{* *}$ & 1 & \\
\hline 7 & $\ln (\mathrm{L})$ & 5.62 & 1.58 & $.19^{* *}$ & $.07^{* *}$ & $.95^{* *}$ & $.67^{* *}$ & $.38^{* *}$ & $-.16^{* *}$ & 1 \\
\hline 8 & $\ln (\mathrm{K})$ & 11.04 & 2.44 & $.63^{* *}$ & $.37^{* *}$ & $.83^{* *}$ & $.95^{* *}$ & $.35^{* *}$ & $-.16^{* *}$ & $.76^{* *}$ \\
\hline 9 & $\ln (\mathrm{K} / \mathrm{L})$ & 5.40 & 1.59 & $.78^{* *}$ & $.50^{* *}$ & $.30^{* *}$ & $.79^{* *}$ & $.17^{* *}$ & $-.09^{* *}$ & $.17^{* *}$ \\
\hline 10 & $\ln (\mathrm{LC} / \mathrm{L})$ & 3.60 & 0.46 & $.54^{* *}$ & $.46^{* *}$ & .38 & $.58^{* *}$ & $.30^{* *}$ & $-.12^{* *}$ & $.28^{* *}$ \\
\hline 11 & $\ln (\mathrm{RD} / \mathrm{L})$ & 3.34 & 1.04 & $.04^{* *}$ & $.04^{*}$ & -0.04 & -0.00 & -0.03 & -0.00 & $-.06^{* *}$ \\
\hline 12 & ECON & 3.26 & 2.03 & $-.12^{* *}$ & -0.02 & 0.01 & $-.042^{*}$ & 0.02 & $-.09^{* *}$ & 0.01 \\
\hline 13 & $\mathrm{IND}$ & 0.40 & 0.24 & $.20^{* *}$ & $-.15^{* *}$ & $-.04^{* *}$ & -0.01 & $-.12^{* *}$ & $.05^{* *}$ & -0.01 \\
\hline 14 & SIZE (Large firm $=1)$ & 0.45 & 0.50 & $.15^{* *}$ & 0.02 & $.76^{* *}$ & $.53^{* *}$ & $.37^{* *}$ & $-.13^{* *}$ & $.81^{* *}$ \\
\hline
\end{tabular}

Note: $\mathrm{p}^{*<0.05, \mathrm{p}^{* *<}<0.01 ; \text { two-tailed tests }}$

(Table 5 continued on next page)

${ }^{6}$ The Bank of Korea investigated PPI. PPI was 86.88 (2005), 87.67 (2006), 88.93 (2007), 96.53(2008), 96.33(2009) and 100.00(2010). PPI in 2010 was the baseline for calculating PPI in other years. 
(Table 5 continued)

\begin{tabular}{|c|c|c|c|c|c|c|c|c|c|c|}
\hline No & Variable & Mean & St.Dev & 8 & 9 & 10 & 11 & 12 & 13 & 14 \\
\hline 1 & $\ln ($ Sale/L) & 5.42 & 1.20 & & & & & & & \\
\hline 2 & $\mathrm{~W}$ & 1.71 & 2.06 & & & & & & & \\
\hline 3 & $\mathrm{~W}^{*} \ln (\mathrm{L})$ & 9.60 & 7.68 & & & & & & & \\
\hline 4 & $\mathrm{~W}^{*} \ln (\mathrm{K})$ & 18.87 & 6.44 & & & & & & & \\
\hline 5 & UNION & 0.46 & 0.50 & & & & & & & \\
\hline 6 & TRAIN & 0.90 & 0.30 & & & & & & & \\
\hline 7 & $\ln (\mathrm{L})$ & 5.62 & 1.58 & & & & & & & \\
\hline 8 & $\ln (\mathrm{K})$ & 11.04 & 2.44 & 1 & & & & & & \\
\hline 9 & $\ln (\mathrm{K} / \mathrm{L})$ & 5.40 & 1.59 & $.77^{* *}$ & 1 & & & & & \\
\hline 10 & $\ln (\mathrm{LC} / \mathrm{L})$ & 3.60 & 0.46 & .53 & .53 & 1 & & & & \\
\hline 11 & $\ln (\mathrm{RD} / \mathrm{L})$ & 3.34 & 1.04 & -0.02 & 0.02 & 0.03 & 1 & & & \\
\hline 12 & ECON & 3.26 & 2.03 & $-.04^{* *}$ & $-.08^{* * *}$ & $-.05^{* i}$ & -0.01 & 1 & & \\
\hline 13 & IND & 0.40 & 0.24 & $.06^{* *}$ & $.10^{* *}$ & -0.02 & $.06^{* *}$ & -0.01 & 1 & \\
\hline 14 & SIZE $($ Large firm $=1)$ & 0.45 & 0.50 & $.62^{* *}$ & $.14^{* *}$ & $.25^{* *}$ & $-.07^{* *}$ & 0.01 & -0.00 & 1 \\
\hline
\end{tabular}

Note: $\mathrm{p}^{*<0.05, \mathrm{p}^{* *}<0.01 ; \text { two-tailed tests }}$

\section{RESULTS}

Table 5 presents the basic statistics. Employee productivity (sales per employee) and employee benefits per employee increased between 2005 and 2009. To check the multicollinearity, variance inflation factors (VIF) were calculated from each regression. The range of VIF is from 1.1 to 1.5 , which is below the rule-of-thumb cut-off of 10 .

Employee benefits are significantly associated with a firm's productivity through the labor-embodied effects, such as labor intensity and turnover rate $(\beta=0.1128, \mathrm{p}<0.01)$ (see Table 6 ). A firm's productivity increases by $11.3 \%$ when employee benefits increase by one unit. The capital-embodied effect (e.g., efficient use of facility and raw materials ) on firm productivity was negative and significant $(\beta=-.0331, \quad p<0.01)$. Considering the two effects, a firm's productivity increases by about $8 \%$ when employee benefits increase by one unit. However, the productivity effect of employee welfare through the disembodied effect (improvement of organizational culture and labor-management relations) is not significant.

Furthermore, labor union, training and R\&D are not significantly related with a firm's productivity. On the otherhand, capital intensity and personnel expense are significantly and positively associated with a firm's productivity $(\beta=0.7759, \quad p<0.01, \beta=0.4424, p<0.01)$. Moreover, the amount of labor has a negative effect on a firm's productivity $(\beta=-1.1796, p<0.01$, implying that a firm's productivity decreases when the number of employee increases.

Fixed effect estimation

Table 6. Results of Regression of Employee Benefits (cluster: firm)

\begin{tabular}{|c|c|c|}
\hline \multirow[b]{3}{*}{ Variable } & \multicolumn{2}{|c|}{ DV: Sales per employee } \\
\hline & \multicolumn{2}{|c|}{ Model 1} \\
\hline & $\boldsymbol{\beta}$ & SE \\
\hline $\mathrm{W}$ & -.1851 & $(.1242)$ \\
\hline $\mathrm{W}^{*} \operatorname{Ln}(\mathrm{L})$ & .1128 & $(.0178)$ \\
\hline $\mathrm{W}^{*} \operatorname{Ln}(\mathrm{K})$ & $-.0331^{* * *}$ & $(.0122)$ \\
\hline UNION & .0976 & $(.1453)$ \\
\hline TRAIN & -.0118 & $(.0750)$ \\
\hline $\operatorname{Ln}(\mathrm{K} / \mathrm{L})$ & $.7759^{\infty \cdots \cdots}$ & $(.1802)$ \\
\hline $\operatorname{Ln}(\mathrm{L})$ & $-1.1796^{* * *}$ & $(.2555)$ \\
\hline $\mathrm{Ln}(\mathrm{RD} / \mathrm{L})$ & -.0128 & $(.0176)$ \\
\hline $\mathrm{Ln}(\mathrm{LC} / \mathrm{L})$ & $.4424^{* * * *}$ & $(.0616)$ \\
\hline $\mathrm{R} 2$ & \multicolumn{2}{|c|}{0.4287} \\
\hline $\mathrm{N}$ & \multicolumn{2}{|c|}{1573} \\
\hline
\end{tabular}


We also compare the effect of employee benefits on firm productivity between the manufacturing and the non manufacturing industries ${ }^{7}$ (see Table 7). The effect of employee benefits on firm productivity in the manufacturing industry is stronger than that in the non-manufacturing industry. In the manufacturing industry, firm productivity through the labor-embodied effect increases by $10.9 \%$ when employee benefits increase by one unit $(\beta=0.1085$, $\mathrm{p}<0.01$ ). In the non-manufacturing industry, firm productivity through the labor-embodied effect increase by $9.2 \%$ when employee benefits increase by one unit $(\beta=0.0919, \mathrm{p}<0.01)$. Hence, the effect of employee benefits through the capital-embodied effect on firm productivity is negative and significant $(\beta=-.0258, \mathrm{P}<0.1)$. However, this effect is very marginal.

The amount of labor has a negative effect on firm productivity. This implies that firm productivity decreases when the number of workers increases in both industries. On the other hand, personnel expense has a positive effect on firm productivity. Thus, the effect of capital intensity on firm productivity is significant only in the non-manufacturing industry $(\beta=0.8278, p<0.01)$. Furthermore, the existence of labor union, the volume of training and the level of $R \& D$ do not have a significant effect on firm productivity in both industries.

Table 7. Results of Regression of Employee Benefits by Industry Type (cluster: firm)

Fixed effect estimation

\begin{tabular}{|c|c|c|c|c|}
\hline & \multicolumn{4}{|c|}{ DV: Sales per employee } \\
\hline & \multirow{2}{*}{\multicolumn{2}{|c|}{$\begin{array}{c}\text { Model 2 } \\
\text { Manufacturing industry }\end{array}$}} & \multicolumn{2}{|c|}{ Model 3} \\
\hline & & Manufacturing industry & \multicolumn{2}{|c|}{ Non-manufacturing industry } \\
\hline & $\beta$ & SE & $\beta$ & SE \\
\hline $\mathrm{W}$ & $\frac{1}{1464}$ & $(.1819)$ & $\frac{1}{-.1836}$ & $(.1843)$ \\
\hline $\mathrm{W}^{*} \mathrm{Ln}(\mathrm{L})$ & $.1085^{* *}$ & $(.0463)$ & $.0919^{* * * *}$ & $(.0246)$ \\
\hline $\mathrm{W}^{*} \mathrm{Ln}(\mathrm{K})$ & -.0367 & $(.0288)$ & $-.0258^{*}$ & $(.0151)$ \\
\hline UNION & .0169 & $(.1951)$ & .2241 & $(.2110)$ \\
\hline TRAIN & -.0131 & $(.0907)$ & .0355 & $(.1307)$ \\
\hline $\operatorname{Ln}(\mathrm{L})$ & $-1.3682^{\ldots \ldots}$ & $(.4561)$ & $-.9348^{\circ \cdots}$ & $(.3673)$ \\
\hline $\operatorname{Ln}(\mathrm{K} / \mathrm{L})$ & .6288 & $(.4296)$ & $.8278^{* * * *}$ & $(.2260)$ \\
\hline $\mathrm{Ln}(\mathrm{LC} / \mathrm{L})$ & $.4131^{*}$ & $(.0836)$ & .3584 & $(.0920)$ \\
\hline $\mathrm{Ln}(\mathrm{RD} / \mathrm{L})$ & -.0143 & $(.0236)$ & -.0087 & $(.0260)$ \\
\hline $\mathrm{W}^{*} \mathrm{D}$ & -.0034 & $(.0096)$ & .0010 & $(.0113)$ \\
\hline R2 & \multicolumn{2}{|c|}{0.3255} & \multicolumn{2}{|c|}{0.5918} \\
\hline $\mathrm{N}$ & \multicolumn{2}{|c|}{867} & \multicolumn{2}{|c|}{706} \\
\hline
\end{tabular}

Note: $* * * \mathrm{p}<0.01, * * \mathrm{p}<0.05, * \mathrm{p}<0.1$

We also compare the effect of employee benefits on firm productivity by firm size because there is a significant difference in terms of productivity and employee benefits according to size ${ }^{8}$. Firm productivity increases by $7.8 \%$ through the labor-embodied effect when employee benefits increase by one unit in large firms $(\beta=.0775, p<0.1)$ (see Table 8). On the other hand, employee benefits are not significantly associated with firm productivity through the labor-embodied effect in small and medium-sized firms. Hence, the effect of employee benefits on firm productivity through the capital-embodied effect is significant and negative in large firms $(\beta=-.0547, p<0.01)$. On the other hand, such effect is positive and significant in small and medium-sized firms $(\beta=.0404, p<0.1)$. Overall, there is no significant effect of employee benefits on firm productivity through the disembodied effect in all firms regardless of firm size. Yet, capital intensity and personnel expense per worker have a positive effect on firm productivity when firm size is large. However, capital intensity is not significantly associated with firm productivity in small and medium-sized firms. Thus, labor union, training and R\&D do not have a significant effect on firm productivity in all firms regardless of firm size. There is no difference in the effect of benefits on a firm's productivity by size. However,

\footnotetext{
${ }^{7}$ The productivity per employee in the manufacturing industry is 5.681 and that in the non-manufacturing industry is 5.1839 . We tested the difference of productivity per employee in both industries and found that there is a significant difference bet ween the $t w o(t=12.72$, $p<0.01)$. The average employee benefits in the manufacturing industry is 1.4901 and those in thenon-manufacturing industry is 1.9169 . There is also a significant difference of employee benefits bet ween the two $(\mathrm{t}=-6.080, \mathrm{p}<0.01)$. This reulst implies that we need to analyze the effect of employee benefits by industry type.

${ }^{8}$ The average value of productivity (i.e., out put per worker) at a large company is 5.6173 , whereas that of small \& medium-sized company is 5.2470 $(\mathrm{t}=9.364, \mathrm{p}<0.01)$. The average value of employee welfare at a large company is 3.1567 , whereas that of small \& medium-sized company is 0.4808 $(\mathrm{t}=49.573, \mathrm{p}<0.01)$. These results imply that we need to analyze the product ivity effect of employee welfare depending on the size of a company. Copyright by author(s); $\underline{\mathrm{CC}-\mathrm{BY}}$

The Clute Institute
} 
labor-embodied effect is strongerin the large firms and capital-embodied effect is strongerin the small and mediumsized firms.

Table 8. Results of Regression of Employ ee Benefits by Firm Size (cluster: firm)

Fixed effect estimation

\begin{tabular}{|c|c|c|c|c|}
\hline & \multicolumn{4}{|c|}{ DV: Sales per employee } \\
\hline & \multicolumn{2}{|c|}{ Model 4} & \multicolumn{2}{|c|}{ Model 5} \\
\hline & \multicolumn{2}{|c|}{ Large firms } & \multicolumn{2}{|c|}{ Small and medium firms } \\
\hline Variable & $\bar{\beta}$ & SE & $\boldsymbol{\beta}$ & SE \\
\hline $\mathrm{W}$ & .2387 & $(.3281)$ & -.2658 & $(.2551)$ \\
\hline $\mathrm{W}^{*} \mathrm{Ln}(\mathrm{L})$ & $.0775^{*}$ & $(.0398)$ & -.0142 & $(.0466)$ \\
\hline $\mathrm{W}^{*} \operatorname{Ln}(\mathrm{K})$ & $-.0547^{* * *}$ & $(.0172)$ & $.0404 *$ & $(.0237)$ \\
\hline UNION & .0331 & $(.1772)$ & .2826 & $(.2484)$ \\
\hline TRAIN & -.0666 & $(.1207)$ & -.0130 & $(.0940)$ \\
\hline $\operatorname{Ln}(\mathrm{L})$ & -.4466 & $(.6146)$ & -.7168 & $(.6625)$ \\
\hline $\operatorname{Ln}(\mathrm{K} / \mathrm{L})$ & $1.2306^{* * *}$ & $(.2452)$ & -.4786 & $(.3549)$ \\
\hline $\operatorname{Ln}(\mathrm{LC} / \mathrm{L})$ & .4994 & $(.0948)$ & $.3625^{\ldots \ldots+}$ & $(.0887)$ \\
\hline $\mathrm{Ln}(\mathrm{RD} / \mathrm{L})$ & .0107 & $(.0234)$ & -.0145 & $(.0282)$ \\
\hline $\mathrm{R} 2$ & \multicolumn{2}{|c|}{0.5088} & \multicolumn{2}{|c|}{0.3095} \\
\hline $\mathrm{N}$ & \multicolumn{2}{|c|}{815} & \multicolumn{2}{|c|}{758} \\
\hline
\end{tabular}

Note: $* * * \mathrm{p}<0.01, * * \mathrm{p}<0.05, * \mathrm{p}<0.1$

\section{DISCUSSION}

We found that benefits per employee has a positive effect on productivity. The result is consistent with those in previous studies (Dulebohn et al, 2008; Allen \& Clark, 1987; Pierce \& Newstorm, 1980; Schein et al, 1977; Choi, 1996; Kang, 2002; Shin, 2005; Kim, 2007; Kwak et al., 2011; Kim, 2012). However, this study analyzes the effect of benefits on employee productivity using two distinctive effects -- the embodied and disembodied effects.

We discovered that the effect of benefits on productivity was made through the embodied effect, not through the disembodied effect. Thus, we need to think about why embodied effect does influence employee productivity. First, the agent theory and transaction cost theory argued that benefits cause moral hazard and free-rider problems among employees. In addition, benefits are evenly distributed to all employees, and not dis proportionately to employees based on individual performance. Therefore, benefits hardly contribute to favorable relationships between management and unions.

Second, the effect of benefits on employees may be deferred. This statement implies that the effect of benefits on employees could be realized in the long-term, not in the short-term. Disembodied effect (e.g., a favorable relationship between management and unions) is usually realized in the long-term. Kruse (1992) suggested that the effect of benefits on employees could be low in the short-term because it is realized after the employees retire or become unemployed. Such deferred effect of benefits could frequently occur in the non-monetary type of benefits, such as pensions and unemployment insurance.

We also discovered the effect of benefits on productivity to be different between firms in the manufacturing industry and the non-manufacturing industry. We suspect that the working conditions in the manufacturing industry are worse than those in the non-manufacturing industry in Korea. Therefore, the effect of benefits on productivity is stronger in the manufacturing industry than the non-manufacturing industry.

The effect of benefits on productivity are compared between large, small, and medium-sized firms. Only embodied effect is significant regardless of firm size. However, large firms realize the effect of benefits through mainly laborembodied effect and small and medium-sized firms through mainly capital-embodied effect. In Korea, the size of benefits in small and medium-sized firms is one third of that in large firms. We suspect that benefits in the small and medium-sized firms are not large enough to increase a labor-embodied effect. 


\section{CONCLUSIONS AND IMPLICATIONS}

This study tested the effect of benefits on employee productivity using the panel data between 2005 and 2009 in Korea. The results suggest that benefits have a positive effect on employee productivity through the labor-embodied effect, such as loyalty for the firm or employee engagement. Therefore, managers need to pay more attention as to why only the labor-embodied effect is significant in explaining the relationship between benefits and employee benefits. In turn, the labor policy and systems need to be improved in order to enhance the disembodied effect. This effect also implies that firms need to know how to operate, manage and improve benefits programs in order to build good employee relations.

The benefits of small and medium-sized firms are less than $60 \%$ of those of large firms in Korea. Such differences increase the relative deprivation of employees in small and medium-sized firms (Cho et al., 2011, Han, 2000, Lee, 2013). The results convey that only the capital-embodied effect is significant in explaining the relationship between benefits and employee productivity. This effect implies that the size of benefits in small and medium-sized firms is not sufficient to generate a labor-embodied effect. Thus, expanding benefits and improving the quality of such benefits in small and medium-sized firms are critical and urgent needs.

\section{AUTHOR BIOGRAPHIES}

Dr Dongug Kang is a professor at Korea National University of Welfare. The author is interested in labour, health, and social welfare policy. E-mail: kdongug@gmail.com

Dr Gun Jea Yu has a Ph.D. in Industrial Labor and Relations from Cornell University and is now an Assistant Professor at the College of Business Administration in Hongik University. His current research is focused on innovation and human resource management. Dr Gun Jea Yu is the corresponding author and can be contracted at: gy52@hongik.ac.kr (corresponding author)

Dr Sang-Jik Lee is interested in social insurance system for workers and labor welfare. Also, he teaches and researches in the area of business administration and venture business.E-mail: 1sj0669@naver.com

\section{REFERENCES}

Allen, S. G., Clark, R. L. and National Bureau of Economic Research. (1987). Pensions and Firm Performance NBER working paper series no $w 2266$

Bloom, S. M. (1985). Employee ownership and firm performance. (Ph D), Harvard University.

Choi, G. (1992). The Socio-economic Characteristics of Korea Employee Benefits. (Ph D), Seoul National University.

Choi, G. (1996). Employee Benefits and Productivity Improving. Company organization and Productivity: A Socio-economic Approach, Sowha publishing co., 237-280.

Dulebohn, J.H., Molloy, J.C., Pichler, S. and Murray, B. (2008). Employee benefits: Literature review and emerging issues. Human Resource Management Review, 19(2), 86-103.

Dreher, G. F., Ash, R. A. and Bretz, R. D. (1988). Benefit coverage and employee cost: Critical factors in explaining compensation satisfaction. Personnel Psychology, 41(2), 237-254.

Hom, Peter W., Caranikas-Walker, Fanny, Prussia, Gregory E. and Griffeth, Rodger W. (1992). A meta-analy tical structural equations analy sis of a model of employee turnover." Journal of Applied Psychology, 77(6), 890-909.

Hong, J. C., Yang, S. D., Wang, L. G., Chiou, E. F., Sun, F. Y. and Huang, T. L. (1995). Impact of Employee Benefits on Work Motivation and Productivity. International Journal of Career Management, 7(6), 10-14

Hong, K. J. (1996). Factors of Employee Benefits in Korea. (Ph D), Seoul National University.

Jensen, Michael C. and Meckling, William H. (1976). Theory of the Firm: Managerial Behavior, Agency Costs and Ownership Structure. Journal of Financial Economics 3(4), 305-360

Jo, S. M. and Park E. J. (2011). Determinants of Corporate Welfare System: Utilizing Workplace Panel Survey. Korea Social welfare Administration Journal 13(3), 197-226.

Jones, D. G. and Kato T. (1993). The Scope, Nature, and Effects of Employee Stock Ownership Plans in Japan. Industrial and Labor Relations Review, 46, 352-367.

Kang, J. S. and Kang, Sung. (1998). The effects of Employee Benefits on Intent to leave among workers. Social Welfare Review, 287-308. 
Kang, Y. K. (2002). Employee Benefits and Productivity. Korean Management Review, 31(2), 529-550.

Kim, J. S. and Campagna A. F. (1981). Effects of Flexible time on Employee Attendance and Performance: A Field Experiment. Academy of Management Journal, 24, 729-741.

Kim, J. H., Park, C. I. and Oh, H. S. (2004). The status of Employee Benefits and Policies. Korea Labor Institute.

Kleiner, M. and Lee Y. (1997). Worker Councils and Unionization: Lessons from South Korea. Labor Relations, 1-16.

Korea Employ ment and Labor Ministry. (2014). Company Labor Cost Survey (2005 2012).

Korea Labor Institute. (2010). Workplace Panel Survey User's Guide. V 1.0.

Kruse, D. L. (1992) Profit Sharing and Productivity: Microeconomic Evidence from the United States. Economic Journal, 102(410), 24-36.

Kwak, N. R., Sim, J. W. and Ko, S. Y. (2011). A Study on the Relation between Employee Benefits and Business Performance. The Journal of Business Education, 25(4), 323-343.

Lee, J. G. (2012). Microeconomics. Seoul: Bubmunsa.

Lee, J. W. (2007). Econometrics. Seoul: Bakyoungsa.

Micelli, M. and Lane, M.(1991). Antecedents of pay satisfaction: A review and extension. In K. Rowland \& G. Ferris (Eds.), Research in personnel and human resources management (235-309). Greenwich, CT: JAI.

Milkovich, G. T. and Newman, J. M. (1990). Compensation (3rd ed.). Homewood, Ill.: Irwin.

Min, I. S. and Choi, P. S. (2010). STATA Panel Analysis. Seoul: Korea STATA Academy.

Ministry of Employ ment \& Labor (Korean Government). (2005 2012). Survey on the Labor Cost of Company.

Nam, M. S. and Kim, D. H. (2009). New Business Analysis. Seoul: Samyoung publishing company.

National Statistical Office. (2005 2012). Korea Statistical Information Service.

Park, C. I. (1997) A Study on Factors of Employee Benefits (1985 1994). (Ph D), Yonsei University.

Park, J. S., Park, J. W. and Jo, J. H. (2008) Modern Financial Management. Seoul: Dasan publishing co.

Pierce, J. L. and Newstrom, J. W. (1980). Toward a Conceptual Clarification of Employee Responses to Flexible Working Hours: A Work Adjustment Approach. Journal of Management, 6(2), 117-134.

Schein, V. E., Maurer, E. H. and Novak, J. F. (1977) Impact of Flexible Working Hours on Productivity. Journal of Applied Psychology, 62(4), 463-465.

Shin, B. C. (2005). An Empirical Analy sis on Productivity Effects of the Employee Welfare in Korea Using Panel Data on the Employee Welfare Fund. Kukje Kyungje Yongu, 11(2), 1-31.

Vroom, V. H. (1964). Work and motivation. New York: J. Wiley.

Williams, M.L. and MacDermid, S. M. (1994). Linkages between employee benefits and attitudinal and behavioral outcomes: A research review and agenda. Human Resource Management Review, 4(2), 131-160. 